\title{
Potential for introducing improved production practices in food legumes with increased food security in Afghanistan
}

\author{
Srinivas Tavva ${ }^{1 *} \odot$, Murari Singh ${ }^{2} \odot$, Javed Rizvi ${ }^{3 \oplus}$, Yashpal Singh Saharawat ${ }^{1}$, Nigamananda Swain ${ }^{1}{ }^{\oplus}$, Kateb Shams ${ }^{4}$
}

IInternational Center for Agricultural Research in the Dry Areas, House, 165 First Section of Karta-e-Parwan - Kabul - Afghanistan.

2International Center for Agricultural Research in the Dry Areas, Yousef El Sukkar Street, Buildings 8 - Amman Jordan.

${ }^{3}$ The World Agroforestry Centre - South Asia Regional Program, Dev Prakash Shastri Marg - 110012 - New Delhi - India.

${ }^{4}$ Ministry of Agriculture, Irrigation and Livestock - Directorate of Agriculture, Irrigation and Livestock, Balkh - Afghanistan. *Corresponding author <s.tavva@cgiar.org>

Edited by: Francesco Montemurro

Received April 08, 2017

Accepted August 23, 2017
ABSTRACT: The restricted maximum likelihood method was used to assess performance following the introduction of improved varieties of chickpea and mungbean (an important source of plant protein in Afghanistan) as compared to local varieties using 242 farmer participatory demonstrations laid out in eight districts in Baghlan, Balkh and Uruzgan provinces in Afghanistan from 2009 to 2012. The impact of the varieties introduced on the enhancement of security of food and nutrition of farmers adopting such technologies was also assessed. Taking an average over the study period, chickpea improved varieties (Madad and Sehat) recorded 56 and $72 \%$ more yield over the local ones, respectively, while in case of mungbean varieties, Mai 2008 and Maash 2008 recorded 22 and $30 \%$ more yield over local ones respectively. Though there is a significant yield difference between the improved and the local varieties of both crops, the difference between the improved varieties of chickpea was not significant while it was significant in the case of mungbean. The study revealed a non-zero variance component for variety type [improved vs. local] $\times$ year within district interaction for the yield of chickpea while none of the interactions in mungbean had a positive variance component. Risk analysis showed that at a chosen probability level of $90 \%$, the improved varieties yielded more than local varieties in both crops $\left(>1.0 \mathrm{tha}^{-1}\right.$ ). Thus, the study highlighted the scope for enhancing the security of both food and nutrition in Afghanistan through improved productivity of pulse crops.

Keywords: improved varieties, chickpea and mungbean, farmer participatory demonstrations, mixed linear model, restricted maximum likelihood estimation

\section{Introduction}

Per capita availability of pulses in Afghanistan was $2.4 \mathrm{~kg}$ during 2013 against the annual pulse dietary requirement of $18.25 \mathrm{~kg}$ per capita required to meet the recommended $50 \mathrm{gm}$ per capita per day. The result of this deficit is chronic malnutrition (FAO, 2016). Limited availability and accessibility of protein rich food sources, instability of food supplies, etc. are some of the many factors that explain the chronic malnutrition in the country (FAO, 2016). Livestock (eggs, meat and dairy products) and food legumes together constitute the major protein sources in Afghanistan (Charity, 2008). Though chickpea and mungbean are the most important food legumes grown in Afghanistan, productivity is less than $1 \mathrm{t} \mathrm{ha}^{-1}\left(0.752 \mathrm{t} \mathrm{ha}^{-1}\right)$ and current production $(60,000 \mathrm{t})$ falls well short of the demand of the growing human population (FAO, 2016). This huge supply-demand gap constrains access to food legumes resulting in insecurity of food and nutrition - a problem which requires immediate attention. Diversification of the wheat based cropping system gives an opportunity to incorporate improved varieties of legumes, which have already been released in similar agro-ecosystems, in Afghanistan. However, low yields, a narrow portfolio of improved varieties, poorly adopted varieties and associated management practices, non-availability of quality seed, etc. are among the constraints identified in pulse production in Afghanistan (ICARDA, 2014). Efforts to select, introduce and popularize high-yielding varieties of different pulse crops have been on-going in fast track mode by international Non-Governmental Organizations (NGOs) such as the International Centre for Agricultural Research in the Dry Areas (ICARDA) in an effort to overcome these constraints (ICARDA, 2014). Witcombe et al. (2005); Sharma and Duveiller (2006); Ortiz Ferrara et al. (2007); Thapa et al. (2009); Rizvi et al. (2012) have successfully used farmers' participatory demonstrations in the dissemination of new technologies. Two mungbean (Mai-2008 and Maash-2008) and two chickpea (Sehat and Madad) varieties released by the Afghan Ministry of Agriculture, Irrigation and Livestock (MAIL) in collaboration with ICARDA are being popularized through farmer participatory demonstrations (ICARDA, 2012). Technological and social/cultural factors constrain such efforts in disseminating new technologies resulting in adoption lag and yield gaps in farmer fields (Erskine and Nesbitt, 2009; Tavva et al., 2013). Growing legumes could make a valuable contribution to cereal systems in terms of increased soil fertility, animal fodder, and increased income (Arif et al., 2015). In spite of these constraints, farmer participatory demonstrations could be an effective and easy way to convince the farmers of the potential advantages of adopting new technologies and provide faster dissemination.

The aim of this study was to assess the performance of introduced improved varieties with associated agronomic practices through farmers' participatory demonstrations in comparison with local varieties of chickpea and mungbean and the effect on food security and enhanced plant protein availability. The current 
study, therefore, tests the hypothesis that improved production practices will have the potential to increase food security in Afghanistan over traditional practices.

\section{Materials and Methods}

The study was conducted in eight districts of Baghlan, Balkh and Uruzgan provinces over four cropping seasons (2009 to 2012) (Table 1). The selection of farmers for laying out on-farm demonstrations was done in close collaboration with the Department of Agriculture and Extension, together with local 'shuras' (a group of senior people in the villages and district, who solve disputes and set priorities for the work required to be done in rural communities) and community representatives for the respective districts. The extension agents from the MAIL played an active role in identifying suitable farmers and working with the farmers in laying out the demonstration plots. In addition, support from local community leaders was also crucial in ensuring the secure movement of staff in the target villages. The number of farmers differed in the various districts over the four years due to limited availability of farmers who have been cultivating pulse crops and their willingness to implement and disseminate the outcomes of on-farm demonstrations to other farmers. A total of 242 farmers' participatory demonstrations $(45$ for chickpea and 197 for mungbean) were laid out in order to popularize improved varieties of chickpea (Sehat and Madad) and mungbean (Mai-2008 and Maash-2008) along with associated best practices. Chickpea lines FLIP 93-58C and FLIP 93-53C which recorded $12 \%$ and $15 \%$ more yield over local varieties were released in 1999 as Sehat and Madad, respectively, for irrigated conditions. Early maturing mungbean lines NM-92 and NM-94 which recorded $79 \%$ and $80 \%$ more yield over local varieties were released in 2008 as Mai-2008 and Maash-2008, respectively, for irrigated conditions. Each demonstration was laid out in an area of $1000 \mathrm{~m}^{2}$. In addition to the use of improved varieties of crops, best agronomic practices such as recommended seed rate (100 and $50 \mathrm{~kg} \mathrm{ha}^{-1}$ for chickpea and mungbean respectively), recommended fertilizers $(50 \mathrm{~kg}$ Urea and $100 \mathrm{~kg}$ Di Ammonium Phosphate (DAP) for chickpea and $50 \mathrm{~kg}$ Urea and $120 \mathrm{~kg}$ DAP for mungbean per ha) and applying weed control methods were included in the demonstrations. On average, chickpea growers used 60-75 kg seed, 70$105 \mathrm{~kg}$ Urea and 95-105 kg DAP per ha while cultivating local varieties. Similarly mungbean growers used 40-45 $\mathrm{kg}$ seed, 70-100 kg Urea and 95-100 kg DAP per ha in cultivating local varieties (ICARDA, 2012). Crops sown through seed broadcasting and fertilizer application resulted in a wide range (in terms of quantity) for both crops. Srinivas and Saharawat (2016) in their study on socio-economic household characterization at selected catchments in Afghanistan reported that farmers growing mungbean in Takhar province used $375 \%$ excess urea and $17 \%$ less DAP and a $215 \%$ excess mungbean seed rate over the recommended, due to lack of awareness about scientific agronomic management practices. It was reported by the ICARDA (2014) that pulse growers need to enhance their knowledge and awareness of good agricultural practices (GAPs) which should be followed in the cultivation of different pulse crops. The yields obtained in the demonstrations were compared with the yields obtained by farmers growing local varieties with local agronomic practices. Data collection was restricted to grain yield (crop cutting method) due only to the limited skills of the participating farmers in recording data on agronomic traits. Remaining plant biomass (residue) is used as animal fodder, and average residue produced for improved variety of chickpea and mungbean was higher than the residue from the local varieties produced by farmers using traditional practices by $34 \%$ and $29 \%$, respectively.

\section{Statistical methods}

The yield was modelled as a mixed linear model to account for the effect of varieties, districts, year within districts and their interactions. Farmers were not able to identify the names of the local varieties and, therefore, it was not possible to identify the genotype of the local varieties. Therefore, all farmers growing local varieties

Table 1 - Number of farmers' participatory demonstrations for chickpea and mungbean during 2009-2012 in various districts of the three provinces of Afghanistan.

\begin{tabular}{|c|c|c|c|c|c|c|c|c|c|c|c|c|c|}
\hline \multirow{2}{*}{ Province } & \multirow{2}{*}{ District } & \multicolumn{3}{|c|}{ Coordinates } & \multicolumn{4}{|c|}{ Chickpea } & \multicolumn{4}{|c|}{ Mungbean } & \multirow{2}{*}{ Total } \\
\hline & & Latitude & Longitude & Altitude & 2009 & 2010 & 2011 & 2012 & 2009 & 2010 & 2011 & 2012 & \\
\hline & & & & $\mathrm{m}$ & & & & & & & & & \\
\hline \multirow{2}{*}{ Baghlan } & Baghlan-e-sannati & $36^{\circ} 19^{\prime} 56.83^{\prime \prime} \mathrm{N}$ & $68^{\circ} 45^{\prime} 47.49^{\prime \prime} \mathrm{E}$ & 476 & - & 4 & - & 2 & - & 30 & - & - & 36 \\
\hline & Pul-i-khumiri & $35^{\circ} 56^{\prime} 37.69^{\prime \prime} \mathrm{N}$ & $68^{\circ} 42^{\prime} 34.33^{\prime \prime} \mathrm{E}$ & 640 & - & - & - & 8 & - & 9 & - & - & 17 \\
\hline \multirow{4}{*}{ Balkh } & Balkh & $36^{\circ} 53^{\prime} 27.3^{\prime \prime} \mathrm{N}$ & $67^{\circ} 11^{\prime} 22.02^{\prime \prime} \mathrm{E}$ & 309 & 5 & 8 & - & - & - & - & - & - & 13 \\
\hline & Dawlatabad & $36^{\circ} 59^{\prime} 3.26^{\prime \prime} \mathrm{N}$ & $67^{\circ} 02^{\prime} 47.25^{\prime \prime} \mathrm{E}$ & 308 & 5 & - & - & - & - & - & - & - & 5 \\
\hline & Khulm & $36^{\circ} 42^{\prime} 9.75^{\prime \prime} N$ & $67^{\circ} 42^{\prime} 28.62^{\prime \prime} \mathrm{E}$ & 439 & 5 & - & - & - & - & - & - & - & 5 \\
\hline & Dehdadi & $36^{\circ} 40^{\prime} 6.66^{\prime \prime} \mathrm{N}$ & $67^{\circ} 01^{\prime} 0.97^{\prime \prime} \mathrm{E}$ & 393 & - & 8 & - & - & 14 & 26 & - & - & 48 \\
\hline \multirow{2}{*}{ Uruzgan } & Dehrawood & $32^{\circ} 37^{\prime} 25.46^{\prime \prime} \mathrm{N}$ & $65^{\circ} 27^{\prime} 23.16^{\prime \prime} \mathrm{E}$ & 1069 & - & - & - & - & - & - & 20 & 39 & 59 \\
\hline & Trinkote & $32^{\circ} 39^{\prime} 59.05^{\prime \prime} \mathrm{N}$ & 65॰54' 13.07" E & 1350 & - & - & - & - & - & - & 20 & 39 & 59 \\
\hline Total & & & & & 15 & 20 & - & 10 & 14 & 65 & 40 & 78 & 242 \\
\hline
\end{tabular}

Source: Author prepared from demonstrations laid out under different projects implemented in Afghanistan in different years. 
were considered as one group and this is one of the limitations of the study. Thus, the variety factor was partitioned in terms of either 'local versus improved' and between improved varieties themselves. The effects of local variety with package may vary from farmer to farmer, and therefore could be more appropriately treated as being random. However, we have no information on the genotype of the local variety nor on the specific package component leading to their estimates. Thus, the local varieties and package effects were treated as an average for all the farmers. When averaged over a large number of farmers, the effect of local variety and package can be assumed to be fixed. Furthermore, the effects of varieties and districts were assumed to be fixed, while that of their interactions involving the year were assumed to be random. The model was fitted using the REML (restricted maximum likelihood) procedure to estimate the fixed effects by their standard errors and variance components of the random effects. The model is described as follows using the directives of GenStat software (VSN International, 2015):

VCOMPONENTS[FIXED $=$ District $\quad+$ Type/Variety] District. Year + District. Year.Type; cons $=$ positive

REML[PRINT $=\mathrm{m}$, comp, means, devi, wald; pse =e] Yield

where the factors denoted as Type, Variety, District, and Year stand for local versus improved variety (two levels), varieties (3), districts (8) and years (4) respectively, and Yield stands for the variable response in grain yield.

A comparison of improved variety vs. local ones has already been carried out in terms of risk measured by the probability of obtaining a targeted amount of yield using the underlying distribution (Anderson, 1974; Haddad et al., 2005). The amount of risk due to adoption of a specific technology was estimated by computing the probability of achieving various fixed target yields under observed distributions as well as modelled normal distribution. The risk (1-safety) under a variety with mean $\mathrm{M}$ and standard error (S) obtained from $\mathrm{N}$ observations was calculated as the probability that the yield in the population of farmers under the variety exceeds $\tau$, a given target. Under the assumption that the yields are normally distributed, the risk can be computed as probability Prob $\left[t>t_{0}\right.$ ] where $t_{0}=(\tau-M) / S$ and the random variable $\mathrm{t}$ has $\mathrm{t}$ - distribution with $\mathrm{N}-1$ degrees of freedom. The risk curves were drawn by plotting the risks against a range of the target yield values.

The effect of the introduction of improved varieties on enhancing food security and plant protein availability through adoption was assessed based on the information collected from the secondary data from Afghan food balance sheets (FAO, 2016).

\section{Results and Discussion}

On average, improved varieties outyielded local ones by 56 and $72 \%$ over the analysis period in the case of chickpea varieties Madad and Sehat, respectively, while in the case of mungbean, Mai-2008 and Maash-2008, yielded 22 and $30 \%$ more, respectively (Table 2). Two improved chickpea cultivars and two mungbean varieties both individually and overall had significantly higher yields than the local ones in each of the demonstrations.

Overall, there is a significant yield difference between improved and local varieties in the case of chickpea $(p<0.01)$. However the two varieties, Sehat and Madad were not significantly different $(p=0.415)$ (Table 3). It is therefore necessary to consider in future that new varieties to be released into the production system should have a yield that is significantly higher than the existing varieties unless the new varieties are associated with special traits (for example, resistance to diseases) which are of importance to the country as perceived by pulse growers (ICARDA, 2014). In mungbean, the difference in yield was not only significant between improved and local varieties $(p<0.01)$ but also between the two improved varieties themselves (Mai-2008 and Maash-2008) $(p<0.05)$ (Table 3).

Table 2 - Estimated mean yields of chickpea and mungbean varieties over all the districts (2009-2012), in Afghanistan.

\begin{tabular}{|c|c|c|c|}
\hline Crop & Variety & Mean & Standard Error (SE) \\
\hline & & $t_{\text {ha }}^{-1}$ & \\
\hline \multirow{3}{*}{ Chickpea } & Madad & 1.492 & 0.130 \\
\hline & Sehat & 1.653 & 0.115 \\
\hline & Local & 0.958 & 0.071 \\
\hline \multirow{3}{*}{ Mungbean } & Mai-2008 & 1.073 & 0.019 \\
\hline & Maash-2008 & 1.145 & 0.027 \\
\hline & Local & 0.882 & 0.017 \\
\hline
\end{tabular}

Source of the table: Own elaboration (2009-2012).

Table 3 - Significance in terms of $p$-value for chickpea and mungbean varieties differences, in Afghanistan.

\begin{tabular}{llccrr}
\hline Crop & Source (varieties) & d.f (numerator) & d.f (denominator) & F-statistic & F-probability \\
\hline \multirow{2}{*}{ Chickpea } & Improved vs Local & 1 & $5.6(86)$ & $18.28^{*}$ & 0.006 \\
& Between improved & 1 & $21.6(45)$ & $0.69^{\text {ns }}$ & 0.415 \\
\hline \multirow{2}{*}{ Mungbean } & Improved vs Local & 1 & $373(380)$ & $117.00^{*}$ & $<0.001$ \\
& Between improved & 1 & $373(197)$ & $4.74^{* *}$ & 0.03 \\
\hline
\end{tabular}

* Significant at $1 \% ;{ }^{*}$ Significant at $5 \%$, ns $=$ not significant; Source: Author calculations; Note: Figures in parentheses indicate the number of participatory demonstrations with improved varieties and farmers growing local varieties. 
Among the different interactions analyzed to identify the source of variation in the yield, the REML method revealed a non-zero variance component for variety Type $\times$ Year within district interaction in the yield of chickpea while none of the interactions in mungbean had a positive variance component (Table 4). This indicates that the performance of chickpea varieties (improved and local) showed a range of variation over all districts during the four cropping seasons $\left(0.24\right.$ to $\left.2.25 \mathrm{t} \mathrm{ha}^{-1}\right)$. The yield of the improved variety was higher than that of the local variety of chickpea in all the districts except Baghlan-esannati (Table 5). However, this difference was not significant ( $p=0.159$ ). Having only two demonstrations for the local varieties (in 2012) over four years in Baghlan-esannati is not sufficient to evaluate the performance of a new variety, as climatic conditions can vary significantly over the years. In the case of mungbean, yield variation across districts during the period under study was in the range of 0.51 to $1.25 \mathrm{t} \mathrm{ha}^{-1}$. Though varieties have been selected and introduced through the farmer participatory method (Sperling and Ashby, 2000), many factors are likely to influence the response of these varieties under farming conditions. The factors which influence the performance of specific technologies can be biotic, social, economic, political and infrastructural and are referred to as a 'Socio-ecological niche' by Ojiem et al. (2006) and 'Option by context interaction' by Nelson and Coe (2014).

Findings of this study are in agreement with a previous study from Afghanistan (Rizvi et al., 2012) which reported substantial variations in mungbean between improved and local varieties. This study provided similar inferences for chickpea.
The risks in obtaining a set of target values are exhibited in Figures 1 and 2. These risks are the probability of achieving a specified target by a technological application. The probability of meeting targeted productivity ( $\left.>1.0 \mathrm{t} \mathrm{ha}^{-1}\right)$ is much higher in the case of improved varieties in comparison to local varieties in chickpea and mungbean respectively. More specifically, in order to achieve a target of $1.0 \mathrm{t} \mathrm{ha}^{-1}$ in chickpea, there is more than a $90 \%$ chance of growing Madad and Sehat while there is only a $20 \%$ chance in a local variety. To expect a target of $1.5 \mathrm{t} \mathrm{ha}^{-1}$, there is no chance under a local variety while Sehat gives more than a 50 $\%$ probability and Madad more than $20 \%$. In mungbean, there is no chance of achieving $1.0 \mathrm{t} \mathrm{ha}^{-1}$ in local varieties while there is a $100 \%$ chance in the case of both improved varieties. The risk curves indicated that in general the improved varieties do indeed enhance the production of legumes for those adopted. There is no observed scenario under which they indicate any risk of resulting in poor performance compared to the local varieties. Thus, risk analysis showed that with a chosen probability of $90 \%$, the improved varieties yield more than local varieties.

Assuming an adoption of introduced varieties of chickpea and mungbean to the extent of $30 \%$ to $50 \%$ of the pulse cultivated area in the three provinces studied, per capita availability of these pulses was estimated to increase by 88 to $146 \mathrm{gm}$ per annum. Though this is a small increment considering the $18.25 \mathrm{~kg}$ annual requirement of pulses, it is certainly a positive step towards achieving increased availability of plant protein (source) and food security in Afghanistan.

Table 4 - Estimates of variance components due to year within districts and interaction with chickpea and mungbean varieties, in Afghanistan.

\begin{tabular}{|c|c|c|c|}
\hline Crop & Variance components & Estimates & Standard Error (SE) \\
\hline \multirow{3}{*}{ Chickpea } & Year within districts & 0.292 & 0.356 \\
\hline & (Improved vs Local) $\times$ Year within districts interaction & 0.058 & 0.045 \\
\hline & Residual & 0.090 & 0.015 \\
\hline Mungbean & Residual & 0.039 & 0.003 \\
\hline
\end{tabular}

Source: Author compilation of results from analysis.

Table 5 - Comparative performance of local and improved varieties of chickpea and mungbean in eight districts of Afghanistan averaged over four years, 2009-2012.

\begin{tabular}{|c|c|c|c|c|c|c|}
\hline \multirow{3}{*}{ District } & \multicolumn{3}{|c|}{ Chickpea (t ha-1) } & \multicolumn{3}{|c|}{ Mungbean (t ha-1) } \\
\hline & \multicolumn{2}{|c|}{$\begin{array}{l}\text { Improved varieties under participatory } \\
\text { demonstrations }\end{array}$} & \multirow{2}{*}{$\begin{array}{l}\text { Local varieties under } \\
\text { farmers' practice }\end{array}$} & \multicolumn{2}{|c|}{$\begin{array}{l}\text { Improved varieties under participatory } \\
\text { demonstrations }\end{array}$} & \multirow{2}{*}{$\begin{array}{l}\text { Local varieties under farmers' } \\
\text { practice }\end{array}$} \\
\hline & Sehat & Madad & & Mai-2008 & Maash-2008 & \\
\hline Balkh & $1.13(5)$ & $1.32(8)$ & $0.53(13)$ & - & - & - \\
\hline Khulm & $1.46(5)$ & - & $0.83(5)$ & - & - & - \\
\hline Dawlatabad & $1.28(5)$ & - & $0.81(5)$ & - & - & - \\
\hline Dehdadi & $1.48(8)$ & - & $0.24(8)$ & $0.69(40)$ & - & $0.51(26)$ \\
\hline Baghlan_e_sannati & $1.45(1)$ & $1.68(5)$ & $1.94(2)$ & $1.09(30)$ & - & $1.06(30)$ \\
\hline Pul-i-khumiri & - & $2.25(8)$ & $1.93(8)$ & $1.11(9)$ & - & $1.07(9)$ \\
\hline Dehrawood & - & - & - & $1.25(20)$ & $1.22(39)$ & $0.93(59)$ \\
\hline Trinkote & - & - & - & $1.24(20)$ & $1.24(39)$ & $0.95(59)$ \\
\hline
\end{tabular}

Source: Author prepared from demonstrations laid out under different projects implemented in Afghanistan in different years; Note: Figures in parentheses indicate the number of participatory demonstrations with improved varieties and farmers growing local varieties. 


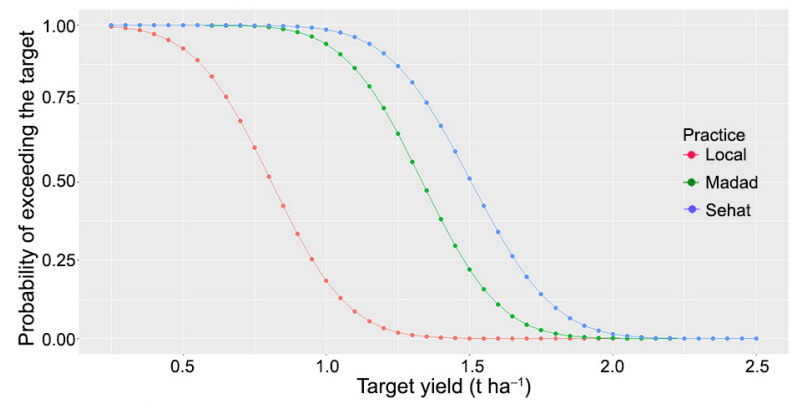

Figure 1 - Risks associated with grain yield from chickpea varieties.

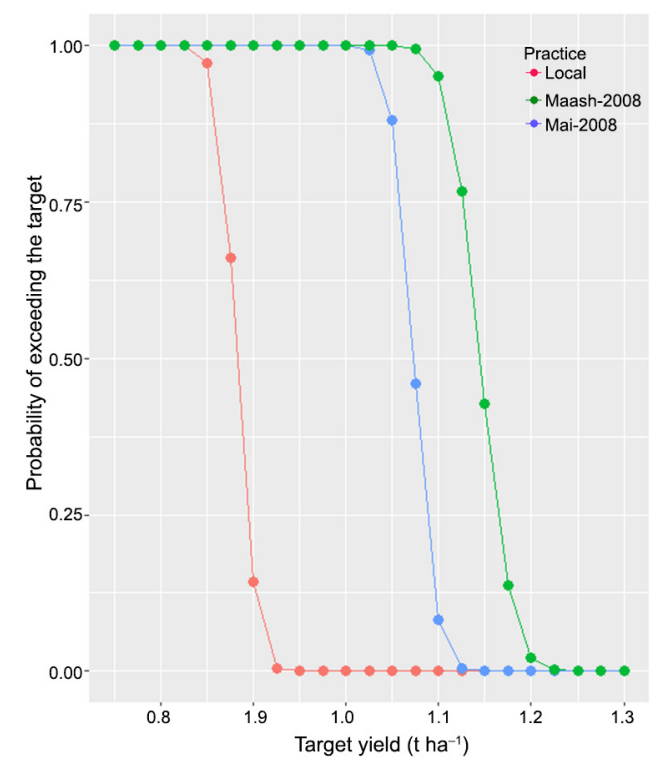

Figure 2 - Risks associated with grain yield from mungbean varieties.

\section{Conclusions}

Substantial yield gain is available to those farmers who adopt improved varieties over local varieties which not only improves yield but also contributes to the security of food and nutrition. Risk assessment indicated positive yield gain when using improved varieties of both chickpea and mungbean. As the onus on popularizing introduced technologies lies with the Department of Extension, MAIL, efforts should consider introducing a variety of crops, especially chickpea, in Afghanistan that have more yield potential than the existing varieties to enhance productivity further. It also highlights the scope for improving the security of food and nutrition in Afghanistan through pulse crops cultivation.

\section{Acknowledgment}

The authors extend thanks to the International Fund for Agricultural Development (IFAD) for their financial support through the project "Increasing Food and
Nutritional Security in Afghanistan through Crop Diversification of wheat based cropping system". The authors gratefully acknowledge the dedicated efforts of ICARDA Provincial teams involved in the field data collection in a very difficult and life threatening environment. Sincere thanks are due to the Ministry of Agriculture, Irrigation and Livestock (MAIL) of Afghanistan and its Provincial Directorates in Baghlan, Balkh, and Uruzgan provinces. Without the full cooperation and support received from various Government departments; local administration; farming communities; village councils, 'Shuras' and 'village elders'; and security updates/assistance providing agencies, it would not have been possible to complete the study. The authors would also like to thank two internal reviewers for their valuable comments in improving the presentation of this paper.

\section{Authors' Contributions}

Conceptualization: Tavva, S., Rizvi, J., Saharawat, Y.S. Data acquisition: Tavva, S., Rizvi, J., Shams, K. Data analysis: Tavva, S., Singh, M. Design of methodology: Tavva, S., Singh, M. Software development: Singh, M. Writing and editing: Tavva, S., Singh, M., Saharawat, Y.S., Swain, N.

\section{References}

Anderson, J.R. 1974. Risk-efficiency in the interpretation of agricultural production research. Review of Marketing and Agricultural Economics 42: 131-184.

Arif, M.; Jalal, F.; Jan, M.T.; Muhammad, D.; Quilliam, R.S. 2015. Incorporation of biochar and legumes into the summer gap: improving productivity of cereal-based cropping systems in Pakistan. Agroecology and Sustainable Food Systems 39: 391398.

Charity, D. 2008. Healthy Food, Happy Baby, Lively Family: Improved Feeding Practices And Recipes For Afghan Children and Mothers. FAO, Rome, Italy.

Erskine, W.; Nesbitt, H. 2009. How can agriculture research make a difference in countries emerging from conflict? Experimental Agriculture 45: 313-321.

Food and Agriculture Organization [FAO]. 2016. FAOSTAT. FAO, Rome, Italy

Haddad, N.; Singh, M.; Mumdouh, Q. 2005. On-farm evaluation of improved Barley production technology packages in Jordan. Jordan Journal of Agricultural Sciences 1: 1-11.

International Centre for Agricultural Research in the Dry Areas [ICARDA]. 2012. Baseline Report for Legume Growers In Balkh in Afghanistan. Increasing Food and Nutritional Security in Afghanistan Through Crop Diversification of Wheat Based Cropping System. ICARDA, Beirut, Lebanon.

International Centre for Agricultural Research in the Dry Areas [ICARDA]. 2014. IFFVC Baseline Report: Community Livestock and Agriculture Program. ICARDA, Beirut, Lebanon.

Nelson, R.; Coe, R. 2014. Transforming research and development practice to support agroecological intensification of smallholder farming. Journal of International Affairs 67: 107-127. 
Ojiem, J.O.; Ridder, N.; Vanlauwe, B.; Giller, K.E. 2006. Socioecological niche: a conceptual framework for integration of legumes in smallholder farming systems. International Journal of Agricultural Sustainability 4: 79-93.

Ortiz Ferrara, G.; Joshi, A.K.; Chand, R.; Bhatta, M.R.; Mudwari, A.; Thapa, D.B.; Sufian, M.A.; Saikia, T.P.; Chatrath, R.; Witcombe, J.R.; Virk, D.S.; Sharma, R.C. 2007. Partnering with farmers to accelerate adoption of new technologies in south Asia to improve wheat productivity. Euphytica 157: 399-407.

Rizvi, S.J.H.; Sharma, R.C.; Srinivas, T.; Tavva, S.; Manan, A.R.; Osmanzai, A.; Siddiqui, S.; Wadan, K.; Hakimi, N.H.; Rahmani, A.R. 2012. Comparative evaluation of local and improved crop varieties through farmer's participation on resource poor farms in Afghanistan. Acta Agronomica Hungarica 60: 11-20.

Sharma, R.C.; Duveiller, E. 2006. Farmer participatory evaluation confirms higher grain yields in spring wheat using a selection index for spot blotch resistance, maturity, and kernel weight. Euphytica 150: 307-317.

Sperling, L.; Ashby, J.A. 2000. Moving participatory breeding forward: the next steps. p. 354-363. In: Collinson, M., ed. A history of farming systems research. CAB International, Wallingford, England.
Srinivas, T.; Saharawat, Y.S. 2016. Socio-Economic Household Characterization at Selected Catchments in Afghanistan. Baseline Survey Report of Integrated Catchment Management and Capacity Building for Improving Livelihoods in Afghanistan. ACIAR, Bruce, Australia.

Tavva, S.; Martini, M.A.; Aw-Hassan, A.; Rischkowsky, B.; Tibbo, M.; Rizvi, J. 2013. Exploring gender roles in agriculture activities: a case of Afghanistan. Indian Journal of Gender Studies 20: 111-134.

Thapa, D.B.; Sharma, R.C.; Mudwari, A.; Ortiz Ferrara, G.; Sharma, S.; Basnet, R.K. 2009. Identifying superior wheat cultivars in participatory research on resource poor farms. Field Crops Research 112: 124-130.

Witcombe, J.R.; Joshi, K.D.; Gyawali, S.; Musa, A.; Johansen, C.; Virk, D.S.; Sthapit, B.R. 2005. Participatory plant breeding is better described as highly client-oriented plant breeding. I. Four indicators of client-orientation in plant breeding. Experimental Agriculture 41: 1-21. 